\title{
A Casual Study on Impact of Green HRM Practices on Organisation Sustainability
}

\author{
Swarnalatha $\mathrm{V}^{*}$
}

\begin{abstract}
Nowadays, our business environment has changed its view from a traditional financial perspective to competency based and strategic based perspective. The green movement across the world has given birth to the concept of Green HRM. The concept became popular owing to the issues in the present business world, ranging from excessive consumption of natural resources, carbon credits, global warming, to pollution. All these results in serious industrial accidents decrease in life span, changes in climate, etc. In general, Green HR deals with practicing all HR activities with environment-friendly concerns. This, in turn, helps in the sustainability of businesses as well as the employees. Nevertheless, there is a wide crack between the HRM and environmental facets. Therefore there is an emerging requirement for research in articulating green HR approaches and their suggestions on general business execution. The reason behind this investigation is to talk about the ideas of green HRM and its impact on organisation sustainability with the help of extensive review of the literature.
\end{abstract}

Keywords: Green HRM, Sustainability, Environment, Strategy, Organisation

\section{Introduction}

Green HRM is an emerging topic in the present scenario. Many definitions are available for the term "green", but according to the

"Assistant Professor, Christ Academy Institute of Law, Bangalore, India; swarna.vyshak@gmail.com 
context of this study, green means it is an act of protecting our mother environment, and it denotes the human quality of being environment friendly. But in the organisational context is considered to be any "activity or service that is performed by organisations or institution by generating or storing renewable energy, recycling existing materials, education and awareness of natural resources" (Mathapati 2013, p. 2). Green HRM will prove to be a good step for promoting a sustainable environment for any organisation. For example, Bank of America, they realised the need for promoting a sustainable environment and decided to go green. Within five years, the bank reduced its paper necessities by $32 \%$ and also started a recycling program internally. The program has attained success by recycling around 30,000 tons of paper every year, which results in conserving about 2,00,000 trees, according to Conserve Energy Future.

These days, the effect of business and industry on environmental disputes is more deceptive (Jackson et al., 2012). In addition to society, public and private business organisations are becoming progressively dedicated to identifying environment-related issues to change in the direction of a sustainable future (Hoffman, 2009).Green HRM mentions that every employee of an organisation ought to support sustainability and to increase response and commitments towards sustainable problems. Green HRM has obtained different meaning for different people.(Vij et al., 2013) Ashok Ramachandran, Director - HR, Vodafone Essar Ltd, views green HR as utilising all worker's to promote sustainable practices and spread employee level of awareness, Anjana Nath Regional Head HR, Fortis healthcare ltd views Green HR as environmentfriendly $H R$ initiative prominent to greater efficacies and effectiveness, smaller cost and enhanced employee engagement levels.

\section{Organisation Sustainability}

Colbert and Kurucz (2007) identified the colloquial definition of sustainability as being able to "keep the business going", while additional commonly used term in this environment denotes to the "future proofing" of business organisations. Boudreau and Ramstad (2005), refer to "achieving success today without 
compromising the needs of the future" for the definition of sustainability. Sustainable growth comprehends a professional business model that forms a significant and consistent view that facilitates long-term protection and development of financial, environmental and social capital. The sustainability of any business organisation depends on the economic and social conditions in the groups in which it works.(Wales, 2013)

The organisation sustainability is facing issues in terms of internal and external sustainability. The issues pertaining to internal sustainability are efficiency and effectiveness of productivity, resources like energy and materials usage/wastage, employee wellbeing and the external sustainability issues are economic progress, community well-being, environment protection, restoration and regeneration, etc. These kinds of predominant sustainability issues can be rectified by the organisations when they adopt Green HRM in their business policies and practices. It has also been mentioned by many researchers in the practice of green HRP, green recruitment, green selection, green training and development, green appraisal, green compensation and rewards, green employee relation and collective bargaining, green grievances handling.(Md. Hosain \& Md. Rahman, 2016; Siyambalapitiya et al., 2018)

\section{Methodology}

The present study focused on desk research through a systematic review of literature from various research articles.

\section{Review of Literature}

(Singh et al., 2020)inspected that in what way green HRM interchanges the connection among green transformational leadership, green innovation, and environmental performance. The sample size was 309 from manufacturing sector small and medium size enterprises. The result shows that green HRM intervenes with regard to the effect on green transformational leadership on green innovation. Similarly, it was found that green human resource management indirectly by means of green innovation impacts a firm's environmental performance. (Siyambalapitiya et al., 2018)they proposed the green HRM practices and support 
improvements in environmental performance. In their study, they identified green HRM practices were evaluated by HR professionals. A total of $106 \mathrm{HRM}$ practices were incorporated with environmental management. This model furthermore recommended for the investigation of the association between green HRM functions and environment management scope that supports the advancement of environmental performance.

(Kim et al., 2019) examined the ways to improve employee's ecofriendly behaviour and hotel environment performance with the help of green HRM. They found green HRM improves employee's organisational commitment, their eco-friendly behavior and hotel environment performance too. They also suggest top management of the hotel and HR managers to establish green HRM practices and policies. Shaikh (2010) emphasizes that green HRM plays an essential role in business to resolve problems linked to the environment by accepting it in the view of management, HR policies, practices, training people and executing policies allied to environmental protection. This will help employees and community associations to use natural resources as they are more economical and support environmentally friendly products. This results in the organisations creating energy-efficient work zones. According to Jain (2012), the green HRM scheme helps organisations to find out various methods and techniques to save costs without losing talented people in the organisation. Mainly green HRM obliges the contribution from all stakeholders of the organisation to prevail in friendly approaches in the overall organizational environment.

(Raj \& Verma, 2019)conceptually examined green HRM practices on environmental performance. The organisation activities are directly related to environmental issues. In India, the energy crisis is found to be severe because the level of regular energy sources is weakening, and there is a lack of inventiveness for introducing the new alternatives energy sources. Hence green practices play a vital role in this scenario. On the other hand, the growth of ecological anxiety and increased pollution, there is a major requirement for any organisation to implement environmentally friendly practices. Hence, it is required to integrate environmental management into human resource management, at present called green HR. 
(Dumont et al., 2016)show that green HRM was openly and indirectly connected to on-role employee workplace green behaviour, but only indirectly related to extra-role green behaviour, through the intervention of spiritual green climate. This finding provides empirical evidence to support the behavioural HRM literature from the following perspectives: (1) HRM practices influence organisational performance through the impact on employee workplace behaviour (Becker \& Huselid, 2006; Wright et al., 2001); (2) traits of HRM practices regulate what worker behaviour is expected to be affected (Bowen \& Ostroff, 2004; Nishii et al., 2008); and (3) HRM may influence employee workplace outcomes through certain underlying mechanisms (Jiang et al., 2012), such as organisational climates (Burke et al., 2002).

(Guerci et al., 2016)grasps green HRM practices as a conservative management practice which business organisation implement for responding to stakeholder services on ecologically friendly disputes. They empirically experiment the different part of green HRM practices, i.e., green acquisition, green training and involvement, and green performance management and compensation, screening in the paramount association between forces on environmental disputes primarily from two particular external stakeholders (customers and regulatory stakeholders) and environmental performance. Their results fabricated on a multirespondent examination in which respondents were HR managers and supply chain managers functioning in Italy. The study results associate the business enterprise in a socio-political context and discovering the role of the factors connected to the external environment of the enterprise play in determining its green HRM practices.

\section{Discussions}

Though it is difficult to implement and practice green HRM at the first time, it can fulfill the primary goals and objectives of a business organization including cost control, eco-friendly environment, corporate social responsibilities, talent acquisition, retain talent, increasing competitive advantage, building a good image and mainly consciousness towards environment and preservation of natural resources and dealing with ethical values. 
Furthermore, it helps in ensuring healthy working conditions and creates a positive environment and boost in employee morale. Moreover, it saves cost by creating a sound working environment by automatically reducing employee fatigue, absenteeism and turnover. Again less usage of paper and recording all information through online can reduce wastage and cost. Most importantly, green HRM practices are reducing government intervention and interference of other law enforcing agencies. Overall, it increases the company's image and stimulates innovation and growth(Md. Hosain \& Md. Rahman, 2016).

The opportunities for green HRM becomes important when they are combined with the main theoretical framework that exposes their effects on environmental cooperation. Ability, motivation and opportunity theory permits them to integrate three essential GHRM factors into one concept, which is considerably dissimilar from the onus of previous studies on one specific GHRM factor, i.e., green training. (Yu et al., 2020)It is recommended that green teams should be made compulsory in all department,(Mandip, 2012)this will create general consciousness and the explicit training in environment management will encourage personal ownership and shift workforce for taking personal action. Several further opinions include asking general awareness speakers like local contractors work to speak on green buildings, recycling planners or experts, decreasing greenhouse gases, crafting green products etc. Similarly, the business can pitch into the standard industry based sustainability journals to keep information about the employees and most recent sustainability trends. One person in the office may be nominated to response on everyday sustainability queries like what can be recycled, green office supply of materials, using double sided printing etc. Furthermore, to evaluate the training prerequisite in environmental management, a training needs analysis (TNA) can be finished with regard to measuring what environmental awareness, knowledge and skills sets an employee requires. (Fernandez et.al. 2003).

\section{Conclusion}

To conclude bases of reviews, with appropriate acquaintance, understanding and execution of possibility of green HR practices, 
business organisations can develop their social and administrative performance remarkably in a workable way that will lead to ensure competitive advantage for a business organisation. It's just a matter of time, once they adopt eco-friendly practices that will result in the betterment of the organisation, overall society and for the world as well. Hence all business organisations sought to incorporate the green problems and practices into their routine activities, corporate policies and strategic decisions related to HR.HR leaders being the supporters of organisational culture and policies are critical to creating a sense of responsibility in every employee in the direction of a sustainable green human resources management. Nevertheless, better changes are necessary so that employees and organisations could move towards greener practices in all their activities.

\section{Reference}

Becker, B. E., \& Huselid, M. A. (2006). Strategic human resource management: Where do we go from here? Journal of Management, 32(6), 898-925.

Bowen, D. E., \& Ostroff, C. (2004). Understanding HRM-fi rm performance linkages: The role of the "strength" of the HRM system. Academy of Management Review, 29(2), 203-221.

Burke, M. J., Borucki, C. C., \& Kaufman, J. D. (2002). Con- temporary perspectives on the study of psychological climate: A commentary. European Journal of Work and Organizational Psychology, 11(3), 325-340.

Dumont, J., Shen, J., \& Deng, X. (2017). Effects of green HRM practices on employee workplace green behavior: The role of psychological green climate and employee green values. Human resource management, 56(4), 613-627.

Fernández, E., Junquera, B., \& Ordiz, M. (2003). Organizational culture and human resources in the environmental issue: a review of the literature. International Journal of Human Resource Management, 14(4), 634-656.

Guerci, M., Longoni, A., \& Luzzini, D. (2016). Translating stakeholder pressures into environmental performance-the mediating role of green HRM practices. International Journal of Human Resource Management,Taylor \& Francis (Routledge), 27(2), 262-289.

Hoffman, A. J.(2009). Shades of green. Stanford Social Innovation Review, 40-49. Web page accessed in April 2018. Available: https://ssir.org/articles/entry/shades_of_green.

Ji, L., Huang, J., Liu, Z., Zhu, H., \& Cai, Z. (2012). The effects of employee training on the relationship between environmental attitude and 
firms'performance in sustainable development. The International Journal of Human Resource Management, 23(14), 2995-3008.

Jiang, K., Lepak, D. P., Hu, J., \& Baer, J. C. (2012). How does human resource management infl uence organisational outcomes? A metaanalytic investigation of mediating mechanisms. Academy of Management Journal, 55(6), 1264-1294.

Kim, Y. J., Kim, W. G., Choi, H. M., \& Phetvaroon, K. (2019). The effect of green human resource management on hotel employees' eco-friendly behavior and environmental performance. International Journal of Hospitality Management, 76, 83-93.

Mandip, G. (2012). Green HRM: People Management Commitment to Environmental Sustainability. Research Journal of Recent Sciences, 1.

Mathapati, C. M. (2013). Green HRM: A strategic facet. Tactful Management Research Journal, 2(2), 1-6.

Md. Hosain, S., \& Md. Rahman, S. (2016). " Green " Human Resource Management - a. Journal of Business and Management, 18, 54-59.

Nishii, L. H., Lepak, D. P., \& Schneider, B. (2008). Employee attributions of the "why" of HR practices: Their effects on employee attitudes and behaviors, and customer satis- faction. Personnel Psychology, 61(3), 503-545.

Raj, R., \& Verma, A. (2019). Green Human Resource Management Practices on Environmental Performance: A Conceptual Note. Our Heritage Journal, 67, 236-245.

Singh, S. K., Giudice, M. Del, Chierici, R., \& Graziano, D. (2020). Green innovation and environmental performance: The role of green transformational leadership and green human resource management. Technological Forecasting and Social Change, 150, 119762.

Siyambalapitiya, J., Zhang, X., \& Liu, X. (2018). Green human resource management: A proposed model in the context of Sri Lanka's tourism industry. Journal of Cleaner Production, 201, 542-555.

Vij, P., Suri, S., \& Singh, S. (2013). International Journal of Marketing and Human Resource Management (IJMHRM), 4(2), 19-25.

Wales, T. (2013). Organisational sustainability: What it is, and why does it matter? Review of Enterprise and Management Studies, 1(1), 38-49.

Yu, W., Chavez, R., Feng, M., Wong, C. Y., \& Fynes, B. (2020). Green human resource management and environmental cooperation: An ability-motivation-opportunity and contingency perspective. International Journal of Production Economics, 219, 224-235. 